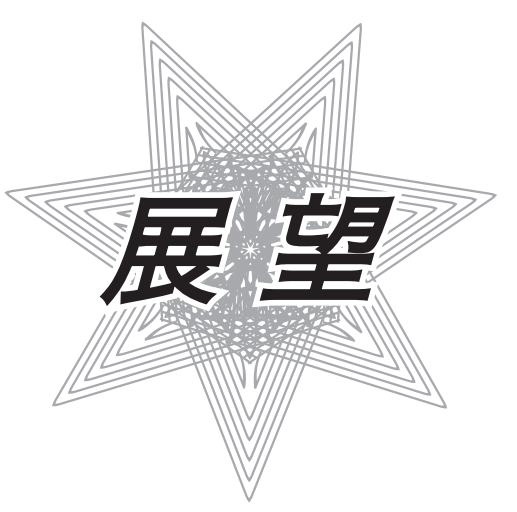

\title{
IoT 繋ぐ
}

\section{平井 良典}

“IoT” (Internet of Things)，皆さんも最近よく目にし，耳にする言葉だと思います。「IoTが各業種にもたらす総合的な 経済価值は 2020 年には世界で 2 兆米ドル近くに達する」とか，「国内の IoT市場におけるユーザー支出額は，2020年ま で年間平均成長率が $15 \%$ 以上で成長し，2020 年には 13.7 兆円に達する」などの予測がされており，この急激に拡大す る巨大市場に多くの企業が注目し，新たなビジネスチャンスを狙っていることでしょうＩoTは「モノのインターネッ ト」と訳され，パソコンやスマートフォンなどに限らずあらゆるモノがインターネットに接続された状態を指し，それ ぞれが繋がりネットワークを形成することで新たな価值が次々と創造されるものといえます。しかし，単にモノがイン ターネットにつながれば価值が生まれるわけではありません。（1）モノに設置したセンサで情報を取得し，(2)インター ネットを通じてその情報を収集, 蓄積し，(3) 蓄積したデー夕を分析して，(4) その分析結果に応じて機器が作動したり, 人が行動したりすることで初めて価值が生まれるものです。このIoT システムの入り口(1)のセンシングの部分は, ガス センサ, 湿度センサ， バイオセンサ，イオンセンサなどのセンサ技術，このセンサや取得したデー夕を送る通信機器の 電源となる電池技術など，電気化学が大いに活躍できる領域といえます．素材メーカーというと一般的にイメージされ るIoT とは遠い位置にあるように思われますが，当社では板ガラスやフッ素化学品などの複雑な製造プロセスに対して IoT の技術やシステムを導入して事業競争力のアップにつなげるスマートファクトリー化に向けて取り組みを開始しよ うとしています。まずはモノづくりの部分で開始しますが，IoT技術の恩恵を得るためにはマーケテイングなども含め たサプライチェーン全体への展開が必須であると考えています。

IoTがモノを繋いだシステムなら，学会はアカデミアと産業界を繋ぐシステムといえます。とりわけ電気化学会は沿 革に「昭和 8 年 4 月 11 日，設立総会が東京・有楽町の電気俱楽部で挙行され，ここに学会と産業界との発意による『電 気化学に関する学術の進歩発展とその工業の発展』を目的とした電気化学協会（電気化学会の前身）が誕生しました.」 と記されているように, 設立当初から両者の協力のもとに発展してきており, その中で数々の電気化学工業技術が開発, 実用化されてきました。また，企業の研究者にとって学会での研究発表は社外の人と繋 がる人脈形成の場でもあります，私の経験から，広く外界の人と繋がることは，自分に 足りないもの，必要なものを気づかせてくれる絶好の機会を与えてくれるものです.

最後に研究者，特に若手の方々へのお願いです。雑学に触れてください。積極的に 外に出て専門以外のことに関心を持ち，いろいろな人と繋がることで多面的な視点を 持つことができるょうになります，知識や技術の引き出しをたくさん作ってください. これらの組み合わせが新しい価值を生み出します。失敗を恐れないでください. 失敗 を恐机て言われたことだけをやっていては，新しい価值を生み出すことはできません。 ネガティブな要素をポジティブに切り替えて考えら机る鈍感力を身に着け，果敢に前 に進んでいただきたいと思います。

皆さんのさらなる活躍とともに, IoTをはじめとする新しい産業を支える学術として 電気化学がさらに進歩発展していくことを期待しています.

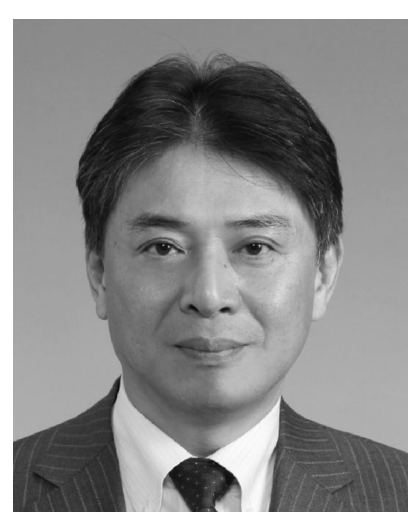

Yoshinori HIRAI 平成 28 年, 29 年度副会長 旭硝子株式会社 取締役常務執行役員 